\title{
Dissemination of Goss's Wilt of Corn and Epiphytic Clavibacter michiganensis subsp. nebraskensis from Inoculum Point Sources
}

Sharon Eggenberger, Department of Plant Pathology and Microbiology, Iowa State University, Ames 50014; Mercedes M. Diaz-Arias, Monsanto Company, St. Louis 63006; Andrew V. Gougherty, Appalachian Laboratory, University of Maryland Center for Environmental Science, Frostburg, 21532; Forrest W. Nutter, Jr., Department of Plant Pathology and Microbiology, Iowa State University; Jeff Sernett, Fifth author: Monsanto Company, Huxley, IA 50124; and Alison E. Robertson, Department of Plant Pathology and Microbiology, Iowa State University

\begin{abstract}
Eggenberger, S., Diaz-Arias, M. M., Gougherty, A. V., Nutter, F. W., Jr., Sernett, J. and Robertson, A. E. 2016. Dissemination of Goss's wilt of corn and Clavibacter michiganensis subsp. nebraskensis from inoculum point sources. Plant Dis. 100:686-695.

Goss's wilt of corn, caused by Clavibacter michiganensis subsp. nebraskensis, has reemerged since 2006 as an economically important disease of corn in in the Midwestern United States. In 2012 and 2013, field plot studies were conducted with a pathogenic, rifampicin-resistant $C$. michiganensis subsp. nebraskensis isolate and a Goss's wilt-susceptible corn hybrid to monitor epiphytic $C$. michiganensis subsp. nebraskensis population densities and the temporal and spatial spread of Goss's wilt incidence originating from inoculum point sources. The randomized complete block trial included three treatments: noninoculated control, inoculum point sources established by wound inoculation, and inoculum point sources consisting of $C$. michiganensis subsp. nebraskensisinfested corn residue. Epiphytic C. michiganensis subsp. nebraskensis was detected on asymptomatic corn leaves collected up to $2.5 \mathrm{~m}$ away from inoculum sources at 15 days after inoculation in both years. The

percentage of asymptomatic leaf samples on which epiphytic $C$. michiganensis subsp. nebraskensis was detected increased until mid-August in both years, and reached 90,55 , and $35 \%$ in wound-, residue-, and noninoculated plots, respectively, in 2012; and 50,11, and 2\%, respectively, in 2013. Although both growing seasons were drier than normal, Goss's wilt incidence increased over time and space from all $C$. michiganensis subsp. nebraskensis point sources. Plots infested with $C$. michiganensis subsp. nebraskensis residue had final Goss's wilt incidence of 7.5 and $1.8 \%$ in 2012 and 2013, respectively; plots with a wound-inoculated source had final Goss's wilt incidence of 16.6 and $14.0 \%$ in 2012 and 2013, respectively. Our findings suggest that relatively recent outbreaks of Goss's wilt in new regions of the United States may be the result of a gradual, nondetected buildup of $C$. michiganensis subsp. nebraskensis inoculum in fields.
\end{abstract}

Since 2006, Goss's bacterial wilt and blight (Goss's wilt) of corn has presented a growing threat to corn production in the western Corn Belt. In recent years, the geographical extent of the disease in the United States has expanded to include Indiana (Ruhl et al. 2009), Minnesota (Malvick et al. 2010, 2012), Texas (Korus et al. 2011), Louisiana (Singh et al. 2015), North Dakota (Friskop et al. 2014), and Missouri (Sweets and Hosack 2014). The known range of Goss's wilt now extends from the southern states of Texas and Louisiana to the Canadian provinces of Alberta, Manitoba, and Ontario; as far west as Wyoming and Colorado; and as far east as Michigan and Indiana (Howard et al. 2015; Jackson-Ziems et al. 2012). Causes for the current outbreaks and pathogen spread have not been identified, but likely factors include planting of susceptible hybrids, weather conditions conducive for infection and disease spread during the growing season, increased continuous corn production, and increased adoption of reduced tillage practices (Givens et al. 2009; Jackson et al. 2007; Langemeier 2012).

The causal agent of Goss's wilt is a gram-positive bacterium, Clavibacter michiganensis subsp. nebraskensis (Vidaver and Mandel 1974), which was first found in Nebraska in 1969. Lesions develop in 7 to 14 days following inoculation (Calub et al. 1974) (A. E. Robertson, unpublished data) or plant injury from wind, hail, or windborne sand (Claflin 1999; Rocheford et al. 1985). Warm temperatures $\left(26\right.$ to $32^{\circ} \mathrm{C}$ ) favor pathogen growth and lesion development (Smidt and Vidaver 1986). Early-season infection is associated

Corresponding author: A. Robertson; E-mail: alisonr@iastate.edu

Accepted for publication 7 September 2015.

http://dx.doi.org/10.1094/PDIS-04-15-0486-RE

(C) 2016 The American Phytopathological Society with higher levels of disease severity and greater yield loss (Pataky 1985).

Recent reports of Goss's wilt outbreaks in new states are of concern, particularly because it is not known how the pathogen was introduced to new states. Although seed-to-seedling transmission can occur, the rate of transmission is low (0.1 to 0.4\%) (Biddle 1990; Biddle et al. 1990; Shepherd 1999), and C. michiganensis subsp. nebraskensis-infested residue is generally regarded as the primary source of inoculum in epidemic outbreaks (Biddle et al. 1985; Jackson et al. 2007; Schuster 1975; Smidt and Vidaver 1986). C. michiganensis subsp. nebraskensis survives for at least 10 months in corn crop residue left on the soil surface but pathogen survival in buried corn residue is greatly reduced (Biddle et al. 1985; Schuster 1975; Smidt and Vidaver 1986).

In 2008, an outbreak of Goss's wilt in Indiana occurred in multiple fields spread over two counties and 6,800 ha (Wise et al. 2009). Small, localized outbreaks of Goss's wilt were reported for the first time in northeast Louisiana in 2013 (Hollier et al. 2014). Seed transmission may be one plausible explanation for these outbreaks but it is also possible that the bacterium was introduced into these states in aerosols or $C$. michiganensis subsp. nebraskensis-infested residue. Storms have been shown to move plant pathogens in aerosols or on infested crop residue (Hirano and Upper 2000; Irey et al. 2006; Lindemann and Upper 1985; Pérombelon 1992).

Relationships between population densities of epiphytic pathogens and the incidence or severity of bacterial disease on leaves have been modeled in some plant pathosystems (Daugrois et al. 2014; Rouse et al. 1985) but not for Goss's wilt in corn. Smidt and Vidaver (1986) suggested that $C$. michiganensis subsp. nebraskensis has an epiphytic phase. They recovered $C$. michiganensis subsp. nebraskensis from the phyllosphere of asymptomatic, field-grown popcorn plants in June, approximately 4 weeks after planting, whereas symptom development was not noted until mid-July (Smidt and Vidaver 1986). Relationships between disease incidence and seasonal trends 
in epiphytic $C$. michiganensis subsp. nebraskensis populations throughout the growing season have not been quantified or described.

To improve our understanding of the epidemiology of Goss's wilt, the objectives of this study were to monitor (i) the spatial spread of epiphytic C. michiganensis subsp. nebraskensis and (ii) the development of Goss's wilt symptoms from inoculum point sources established within plots.

\section{Materials and Methods}

Bacterial strains and inoculum production. A pathogenic, rifampicin-resistant strain of $C$. michiganensis subsp. nebraskensis (isolate 91-R) was obtained from Charles Block (United States Department of Agriculture Plant Introduction Station, Ames, IA). The strain was grown at $24^{\circ} \mathrm{C}$ on solidified nutrient broth yeast extract agar amended with $50 \mathrm{mg}$ of rifampicin, $100 \mathrm{mg}$ of cycloheximide (Gleason et al. 1991), and $20 \mathrm{mg}$ of chlorothalonil (Bravo Ultrex WDG; Syngenta Crop Protection LLC, Greensboro, NC) per liter $(\mathrm{NBYCR}+\mathrm{B})$. Inoculum was prepared from 5-day-old colonies that were suspended in $10 \mathrm{mM}$ phosphate-buffered saline + Tween 20 (1 drop liter ${ }^{-1}$; pH 7.4) (PBST) (Saalau-Rojas and Gleason 2012). Inoculum concentration was measured with a spectrophotometer at $600 \mathrm{~nm}$ and adjusted to approximately $1 \times 10^{6} \mathrm{CFU} \mathrm{m}{ }^{-1}$ according to an optical density curve obtained previously (A. Robertson, unpublished data). Pathogen-infested residue for 2012 field studies was obtained from greenhouse-grown corn plants that had been artificially inoculated with $C$. michiganensis subsp. nebraskensis 91-R. Leaves with well-developed Goss's wilt lesions were air dried and stored at room temperature until needed. In 2013, symptomatic leaves saved from the previous year's 91-R-inoculated field trial were used as $C$. michiganensis subsp. nebraskensis-infested residue. One week prior to inoculation, the presence of $C$. michiganensis subsp. nebraskensis 91-R in the stored leaves from 2012 was confirmed by suspending leaf tissue in PBST and plating aliquots on $\mathrm{NBYCR}+\mathrm{B}$.

Within-field dispersal of epiphytic $C$. michiganensis subsp. nebraskensis and Goss's wilt from inoculum point sources. A Goss's wilt-susceptible hybrid, DeKalb DKC55-09 (rated 7 on a 1-to-9 scale, where 1 is excellent and 9 is poor) was planted at the Iowa State University Horticulture Research Station in Gilbert on 8 June 2012 and 21 June 2013. In both years, trials were established in newly tilled areas that had been used for grass hay production in previous years. Plots were $6 \mathrm{~m}$ wide by $9 \mathrm{~m}$ in length and contained approximately 400 plants, equivalent to 50 plants in eight rows, with $76 \mathrm{~cm}$ between rows and approximately $15-\mathrm{cm}$ plant spacing within rows $\left(86,500\right.$ plants $\left.\mathrm{ha}^{-1}\right)$. Plots were bordered on all sides by four rows $(3 \mathrm{~m})$ planted with a Goss's wilt-resistant hybrid (DeKalb DKC56-55; rated 2 on a 1-to-9 scale, where 1 is excellent and 9 is poor). The experimental design was a randomized complete block design with three treatments: a noninoculated control, an inoculum point source established by wound inoculation (to simulate seedling infection resulting from seed transmission of $C$. michiganensis subsp. nebraskensis), and an inoculum point source consisting of C. michiganensis subsp. nebraskensis-infested corn residue. Point sources of inoculum were established at crop development stage V3 (Abendroth et al. 2011) on 25 June 2012, 17 days after planting (DAP), and at crop development stage V4 on 10 July 2013, 19 DAP. The four plants in the center of each wound-inoculated plot were inoculated by pinpricking with modified tongs (Calub et al. 1974) dipped in a suspension of $C$. michiganensis subsp. nebraskensis strain 91-R at $10^{6} \mathrm{CFU} \mathrm{ml}^{-1}$. For the residue-inoculated treatment, approximately $50 \mathrm{~g}$ of dry $91-\mathrm{R}$-infested corn leaves were placed on the ground in a $0.4-\mathrm{m}^{2}$ area at the base of the center four plants, and spread to cover at least $80 \%$ of the soil surface. Leaf residue was held in place with $1.3-\mathrm{cm}$ mesh hardware cloth and pinned with wire landscape-cloth staples.

Visual assessments of disease incidence. Assessments were made on five dates in 2012 (10, 20, and 24 July and 17 and $30 \mathrm{Au}-$ gust; crop development stages V8 to R5) and seven dates in 2013 (11 and 26 July; 7, 15, and 26 August; and 4 and 19 September; crop development stages V4 to R5) (Table 1). All plants within plots were assessed visually for the presence or absence (incidence) of Goss's wilt on each date, and the presence or absence of symptoms on each plant was recorded.

Sample collection to determine epiphytic $C$. michiganensis subsp. nebraskensis population densities. In 2012, epiphytic C. michiganensis subsp. nebraskensis population densities were quantified using leaves sampled from 16 individual corn plants in each plot. A cross-sampling pattern was used to monitor both across-row and within-row spread of epiphytic $C$. michiganensis subsp. nebraskensis from point sources. Leaves were collected on the same five dates when visual assessments for disease incidence were made. On the first two dates, two leaves (one from the upper canopy and one from the lower canopy) were collected from the center plant in all eight rows (i.e., the 25th plant in each row), and the remaining eight plants were randomly selected (using a random number generator) from within the center two rows (i.e., the fourth and fifth rows). On the three subsequent dates, across-row samples were collected from the 24th, 26th, and 27th plants, respectively, in all eight rows. Within-row samples were located close to plot centers at the beginning of the season but, as the season progressed, leaf samples were collected from random plants located along the entire length of the plot. Leaves were placed in plastic bags and transported in coolers with ice. In the lab, leaf samples were kept at $5^{\circ} \mathrm{C}$ until processing, which was completed within 2 days.

In 2013, the sampling procedure was modified in order to increase the number of plants sampled on each date and to quantify the increase of epiphytic populations over time at distances relative to inoculum point sources. The center two rows of the plots were divided into 100.9 -m-long quadrats, which were sampled to quantify the spatial spread of $C$. michiganensis subsp. nebraskensis within rows, as described by Nutter et al. (1998). Two additional 0.9-m quadrats were designated at the centers of rows 2 and 3 and rows 6 and 7 , to monitor the spread and increase of epiphytic $C$. michiganensis subsp. nebraskensis populations across rows. Four asymptomatic leaves were collected from each quadrat (one upper-canopy leaf and one lower-canopy leaf from two plants) and processed as a bulk sample for dilution plating. Plants in quadrats with inoculum sources were left intact early in the season to avoid removing leaves in the area that served as the inoculum source. Leaves were collected from all quadrats on the last sample date. Repeat sampling of previously sampled plants was avoided until later in the season, when all plants in the center two rows had been sampled once. Workers donned fresh disposable gloves before moving from one plot to the next. Samples were collected on seven dates in 2013, from 24 July to 16 September (crop development stages V8 to R5; Table 1). Quadrat samples were bagged separately and placed in a cooler with ice for transport to the lab. Samples were stored at $5^{\circ} \mathrm{C}$ and processed within 2 days.

Dilution plating to determine $C$. michiganensis subsp. nebraskensis population densities. In 2012, pieces of healthy, green leaf tissue, approximately 10 to $12 \mathrm{~cm}$ long, were taken from both the tip and the middle of each sampled leaf. Fresh weight of the leaf pieces (combined weight $=2.5$ to $6.0 \mathrm{~g}$ ) was recorded. All four pieces from a plant were combined and placed in test tubes with $20 \mathrm{ml}$ of sterile PBST (Beattie and Marcell 2002). Tubes were sonicated for 7 min in a B200 ultrasonic cleaner (Branson Ultrasonics Corp., Danbury, CT) filled with ice water, then packed in crushed ice. Tubes were vortexed for $15 \mathrm{~s}$; and $0.1-\mathrm{ml}$ aliquots were transferred immediately to sterile $1.5-\mathrm{ml}$ microcentrifuge tubes filled with $0.9 \mathrm{ml}$ of sterile $1 \times$ PBST buffer. Single $0.1-\mathrm{ml}$ aliquots of the original suspension and a $10^{-1}$ dilution were plated on $\mathrm{NBYCR}+\mathrm{B}$ agar plates and spread with sterile glass beads. Cultures were inspected 5 or 6 DAP, and the presence or absence of typical C. michiganensis subsp. nebraskensis colonies was recorded. The lower detection limit for this procedure, based on buffer volumes used and plated, was $2.0 \times 10^{2} \mathrm{CFU}$ sample ${ }^{-1}$.

In 2013 , leaf pieces approximately 10 to $15 \mathrm{~cm}$ long were taken from the tip and middle of the four leaves from each quadrat. Pieces were combined, placed in a 118-ml Whirl-Pak bag (Nasco, Fort Atkinson, WI), and weighed. The average fresh sample weight was 
6 to $7 \mathrm{~g}$. PBST $(20 \mathrm{ml})$ was added to each bag and samples were shaken briefly, then sonicated and packed in ice as in 2012. Prior to plating, bagged samples were squeezed rapidly 10 times and then shaken vigorously for $10 \mathrm{~s}$ to ensure adequate mixing of the suspension. Ten-fold dilutions were prepared by transferring $0.9 \mathrm{ml}$ of the original suspension to an empty well in a sterile, deep-well polypropylene plate (similar to PlateOne, $962.0-\mathrm{ml}$ wells/plate; USA Scientific, Ocala, FL), and then transferring 0.1-ml aliquots to wells filled with $0.9 \mathrm{ml}$ of sterile PBST. At each step, suspensions were mixed by pipetting 10 times with fresh pipette tips. Six $10-\mathrm{ml}$ drops of the $10^{\circ}, 10^{-1}$, and $10^{-2}$ dilutions were placed on two plates of $\mathrm{NBYCR}+\mathrm{B}$ media using an electronic multichannel pipette. A total volume of $0.12 \mathrm{ml}$ per dilution was drop plated. The lower detection limit for the procedure was $1.7 \times$ $10^{2} \mathrm{CFU}$ sample ${ }^{-1}$. The protocol was adapted from the procedure described by Chen et al. (2003). Agar plates were incubated in the dark at room temperature.

Colonies on $\mathrm{NBYCR}+\mathrm{B}$ were counted $5 \mathrm{DAP}$ and recounted on day 6. Colony counts were expressed as CFU g ${ }^{-1}$ fresh leaf tissue ( $\log _{10}$ scale). The proportion of plant samples (in 2012) or quadrat samples (in 2013) with epiphytic C. michiganensis subsp. nebraskensis populations was calculated for each plot and sample date and recorded as the incidence of epiphytic $C$. michiganensis subsp. nebraskensis.

Data analysis. Disease incidence was defined as the number of plants with Goss's wilt symptoms/the total number of plants per plot $(n=400) \times 100$ (Campbell and Madden 1990). Treatment differences in disease incidence on individual sampling dates were analyzed using PROC MIXED (SAS Institute, Cary, NC). Significant treatment-sample date interactions $(P \leq 0.05)$ were observed in both years; therefore, incidence data from each sample date were analyzed separately. In both years, one or more treatments had fewer than five assessment dates with symptoms present; therefore, change in disease incidence over time was not modeled (Campbell and Madden 1990; Madden et al. 2007; Nutter 1997). Instead, average rates of disease increase over time were calculated and treatment differences were compared using $t$ tests. Unless stated otherwise, all treatment means were compared using Tukey's test for mean separations $(P=0.05)$.

Epiphytic C. michiganensis subsp. nebraskensis incidence was graphed using percentages but incidence of $C$. michiganensis subsp. nebraskensis in samples was recorded as count data. Initial analyses of binomial count data detected significant treatment-days after inoculation interactions; therefore, data for specific sample dates were analyzed separately using SAS PROC GLIMMIX, with treatment and replication as fixed effects. Total counts of $C$. michiganensis subsp. nebraskensis-positive samples for the growing season were also compared using PROC GLIMMIX. Mean epiphytic C. michiganensis subsp. nebraskensis population densities on individual sampling dates in 2013 and season-long averages were compared using SAS PROC MIXED.

Spatial pattern analyses. Three methods were used to analyze the spatial dynamics of Goss's wilt within corn plots. Ordinary runs analysis and black-white joins analysis (Byamukama et al. 2011) were used to determine aggregation in the spatial pattern of Goss's wilt-infected plants within plots. A distance-based analysis was used to describe the spread of Goss's wilt incidence within the plots (Gougherty and Nutter 2015).

Ordinary runs analyses were conducted using data for individual plots and visual assessment dates to assess the spatial aggregation of symptomatic plants in both years (Byamukama et al. 2011; Madden et al. 1982). A run is defined as a series of like events (i.e., a series of healthy plants or a series of Goss's wilt-infected plants). Statistical significance was determined by calculating a $z$-statistic, which compares the actual number of runs in a plot to the number of runs expected if the infected plants were randomly distributed. This analysis tests the null hypothesis that infected plants are randomly distributed within the plot. Significant spatial aggregation of Goss's wilt-infected plants within a plot was identified when the $z$-statistic was less than $-1.64(P \leq 0.05)$ (Byamukama et al. 2011).

Black-white joins analysis (Byamukama et al. 2011; Sawada 1999) was also conducted for each sampling period in both years. A Microsoft Excel macro, Rookcase, was used to perform the black-white joins analysis (Sawada 1999). This analysis also assesses the aggregation of similar classes but black-white joins analysis can be used to measure relationships in two dimensions simultaneously (e.g., within and across rows). A black-white join is an adjacency between two different classes (i.e., an infected plant and a healthy plant). The analysis simulates 1,000 randomizations of the observed distribution within a plot in order to determine whether the observed pattern is significantly different from a randomized pattern. As with ordinary runs analysis, a $z$-statistic is calculated which compares the observed number of black-white joins to the expected number of joins under the null hypothesis of randomization.

Distance-based analyses. In order to get a measure of the spread of Goss's wilt incidence within plots, we used a nearest-neighbor analysis to determine the distance from newly infected plants to the nearest infected plant detected during a previous sampling period (Gougherty and Nutter 2015). All nearest-neighbor distances for individual plots and visual assessment dates were used for analysis, and distances to

Table 1. Timeline of activities performed in inoculum-point-source field studies conducted at the Iowa State University Horticulture Research Farm, Gilbert, in 2012 and $2013^{\mathrm{a}}$

\begin{tabular}{|c|c|c|c|c|c|c|}
\hline \multirow[b]{2}{*}{ Activities } & \multicolumn{3}{|c|}{2012} & \multicolumn{3}{|l|}{2013} \\
\hline & Date & GS & DAP & Date & GS & DAP \\
\hline Planting & 8 June & & 0 & 21 June $(0)$ & $\ldots$ & 0 \\
\hline Inoculation & 25 June & V3 & 17 & 10 July (19) & V4 & 19 \\
\hline Sampling for epiphytic bacteria & 10 July-30 August (5 dates) & V8 to R5 & 32 to 83 & 24 July-16 September (7 dates) & V4 to R5 & 33 to 87 \\
\hline \multicolumn{7}{|l|}{ Date bacteria first detected in } \\
\hline Inoculated treatment & 10 July & V8 & 32 & 24 July & V8 & 33 \\
\hline Residue treatment & 10 July & V8 & 32 & 24 July & V8 & 33 \\
\hline Noninoculated treatment & 24 July & V13 & 46 & 7 August & V11 & 47 \\
\hline All plots & 17 August & $\mathrm{R} 3$ & 70 & $\mathrm{n} / \mathrm{a}$ & - & $\mathrm{n} / \mathrm{a}$ \\
\hline Visual assessments & 10 July-30 August (5 dates) & V8 to $\mathrm{R} 5$ & 32 to 82 & 11 July-19 September (7 dates) & V4 to R5 & 20 to 90 \\
\hline \multicolumn{7}{|l|}{ Date lesions first recorded in } \\
\hline Inoculated treatment & 10 July & V8 & 32 & 22 July $^{\mathrm{b}}$ & V7 & 31 \\
\hline Residue treatment & 24 July & V13 & 46 & 7 August & V11 & 47 \\
\hline Noninoculated treatment & 24 July & V13 & 46 & $\mathrm{n} / \mathrm{a}$ & $\ldots$ & $\ldots$ \\
\hline All plots & 30 August & $\ldots$ & 83 & $\mathrm{n} / \mathrm{a}$ & $\ldots$ & $\ldots$ \\
\hline
\end{tabular}

a Clavibacter michiganensis subsp. nebraskensis, the causal agent of Goss's wilt and leaf blight of corn, was introduced at plot centers either by leaf-prick inoculation or by placing dried, C. michiganensis subsp. nebraskensis-infested corn leaves on the soil surface. GS = corn growth stage (Abendroth et al. 2011), $\mathrm{DAP}=$ days after planting, and $\mathrm{n} / \mathrm{a}=$ not applicable.

b Targeted inspection of inoculated plants was made on 22 July but not all plants were inspected on this date. The second census assessment was made on 26 July. 
50 and $95 \%$ of newly infected plants ( $\mathrm{D}_{50}$ and $\mathrm{D}_{95}$, respectively) within plots were calculated. Analysis of nearest-neighbor distances was performed using sequential visual assessment dates, as well as on the final cumulative dataset. Treatment differences in $\mathrm{D}_{50}$ and $\mathrm{D}_{95}$ distances were assessed by analysis of variance.

Weather data. Precipitation and daily high and low temperature data for all locations were downloaded from the Iowa Environmental Mesonet (Fig. 1; http://mesonet.agron.iastate.edu/agclimate/). In both years, monthly precipitation in June, July, and August was 40 to $80 \%$ below 30-year historical averages. Daily mean temperatures were warmer than average in June and July 2012 and June 2013. A wind and rain storm on 25 July 2012 (47 DAP) caused considerable leaf damage and plant lodging in research plots at the Horticulture Station.

\section{Results}

Incidence of Goss's wilt symptoms. In 2012, Goss's wilt lesions (large, yellow to gray-green lesions, with necrotic centers and characteristic "freckles" on lesion edges) were present on all woundinoculated plants on 10 July, 15 days after inoculation (DAI; Table 1). Symptomatic plants were observed in two residueinoculated plots and one noninoculated plot on 24 July (29 DAI, crop development stage V13). On the last sample date (30 August, approximate crop development stage R5), all 12 plots contained plants with Goss's wilt lesions. Mean incidence of Goss's wilt at the end of the season was $16.6,7.5$, and $0.9 \%$ in the wound-inoculated, residueinoculated, and noninoculated treatments, respectively (Fig. 2A). Orthogonal contrasts of least-squares means confirmed that disease incidence in the residue-inoculated plots was lower than incidence in the wound-inoculated plots on all dates in $2012(P \leq 0.0001$ on the first four dates and $P=0.0705$ on 30 August). Mean disease incidence for the entire growing season was lowest in the noninoculated plots $(P=0.0677)$; however, on any individual sampling date, disease incidence in noninoculated control plots was not significantly different from incidence in residue-inoculated treatments $(P>0.10)$.

In 2013, the timing of early symptom development in woundinoculated and residue-inoculated treatments was very similar to that seen in 2012 (Table 1); however, Goss's wilt symptoms were never observed in the noninoculated control plots. At the end of the 2013 growing season, 14.0, 1.8, and $0.0 \%$ of the plants in the woundinoculated, residue-inoculated, and noninoculated plots, respectively, had Goss's wilt lesions (Fig. 3A). In 2013, disease incidence in the wound-inoculated treatment was higher $(P<0.01)$ than incidence in the residue-inoculated treatment on all visual assessment dates. Mean incidence in the residue-inoculated plot was not significantly different from zero and hence, not different from the noninoculated treatment on any date. Mean incidence for the entire growing season was lowest in the noninoculated treatment $(P=0.0853)$.

In 2012, disease incidence in wound-inoculated plots increased at the average rate of $0.30 \% \mathrm{day}^{-1}$. This was twice as fast as the rate of increase in residue-inoculated plots $\left(0.15 \%\right.$ day $\left.^{-1}\right)$, and 15 times faster than the rate of increase in noninoculated plots $\left(0.02 \% \mathrm{day}^{-1}\right)$. Rates of increase fluctuated through during the season, and the fastest rates for disease increase were observed at the end of the season (Fig. 2A). In general, slower rates of disease increase were observed in 2013. In the second year of the study, the incidence of plants with symptoms increased at the average rate of $0.24 \%$ day $^{-1}$ in wound-inoculated
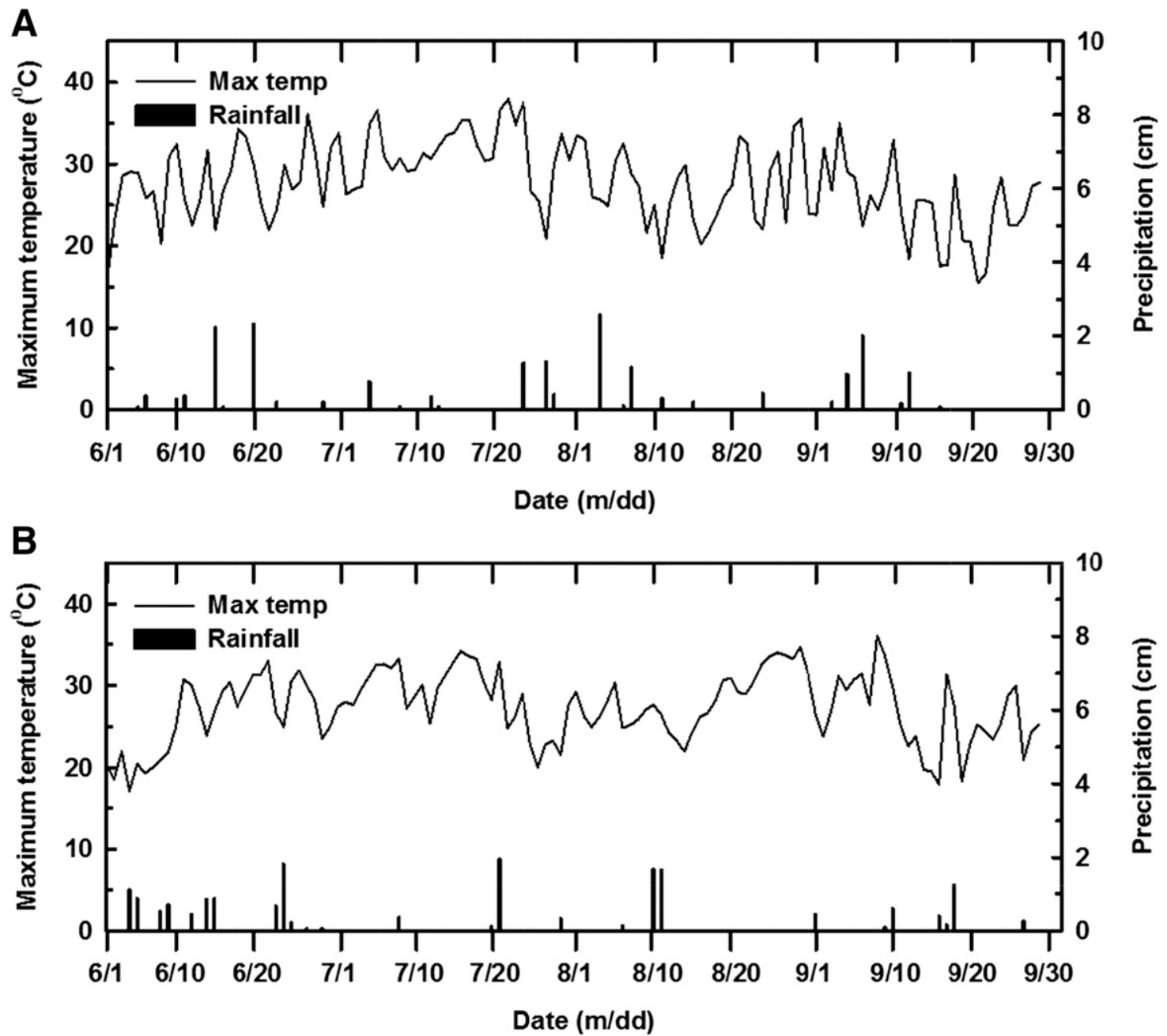

Fig. 1. Daily maximum temperature and precipitation at the lowa State University Horticulture Research Farm near Gilbert, IA during the A, 2012 and B, 2013 corn growing seasons. 
plots, which was seven times faster than the rate of increase in residueinoculated plots $\left(0.03 \%\right.$ day $^{-1} ;$ Fig. 3A). The fastest rates of disease increase in 2013 occurred during the period from 26 August to 4 September.

Incidence of epiphytic C. michiganensis subsp. nebraskensis on asymptomatic samples. In both years, $C$. michiganensis subsp. nebraskensis was detected on asymptomatic green leaves collected from wound-inoculated and residue-inoculated plots on the first sampling dates, which occurred 15 and 14 DAI in 2012 and 2013, respectively (Table 1). On these dates, C. michiganensis subsp. nebraskensis-positive samples were collected as far as $2.5 \mathrm{~m}$ from inoculum locations.

In 2012, the incidence of plants with detectable populations of epiphytic C. michiganensis subsp. nebraskensis increased until $17 \mathrm{Au}-$ gust (Fig. 2B), when rifampicin-resistant $C$. michiganensis subsp. nebraskensis was recovered from 90,55 , and $35 \%$ of samples collected from wound-inoculated, residue-inoculated, and noninoculated plots, respectively $(P \leq 0.05)$. The incidence of $C$. michiganensis subsp. nebraskensis-positive samples in wound-inoculated and residueinoculated inoculated plots was similar on the first three collection dates $(P>0.10)$, but greater in wound-inoculated plots on the last two dates $(P<0.05)$ (Fig. 2B). Epiphytic $C$. michiganensis subsp. nebraskensis was detected on $41.5 \%, 25.7 \%$, and $10.4 \%$ of all samples collected during the growing season from wound-, residue-, and noninoculated treatments, respectively $(P<0.0004)$.

In the noninoculated control treatment, rifampicin-resistant $C$. michiganensis subsp. nebraskensis was first detected on one plant in a single noninoculated control plot on 20 July 2012. On 17 and 30 August, the pathogen was detected in all four control plots, and sample incidence within plots ranged from 6 to $73 \%$ on these two dates. Throughout the 2012 season, asymptomatic-tissue samples from noninoculated plots had the lowest incidence of $C$.

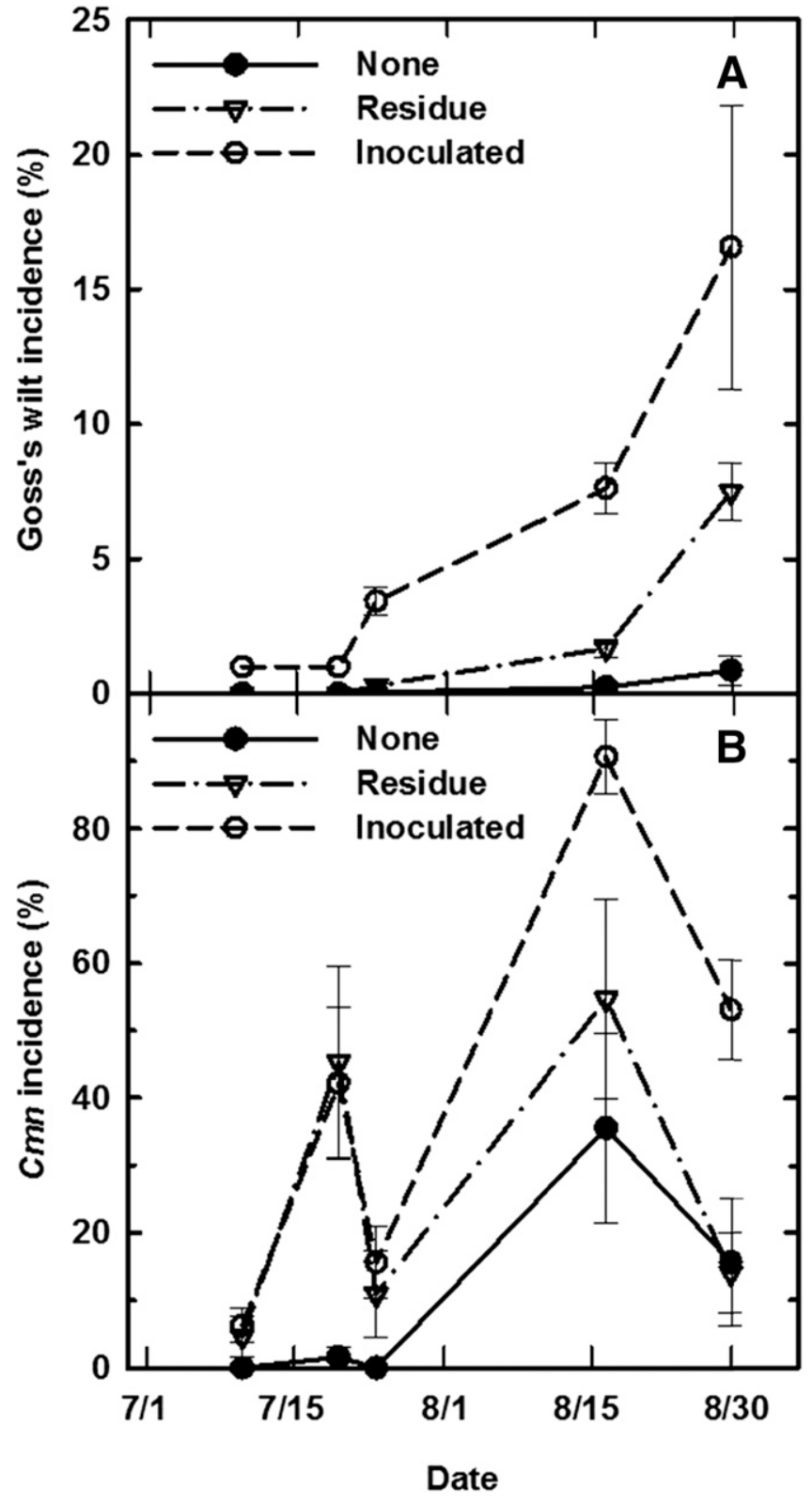

Fig. 2. A, Incidence (\%, $n=400)$ of corn plants (DeKalb DKC55-09) with Goss's wilt symptoms and $\mathbf{B}$, incidence of asymptomatic plants on which epiphytic Clavibacter michiganensis subsp. nebraskensis was detected in 2012. On 25 June (17 days after planting), inoculum point sources were established in plots near Gilbert, IA by pinprick inoculation of four plants or by placing C. michiganensis subsp. nebraskensis-infested residue at the base of four plants.

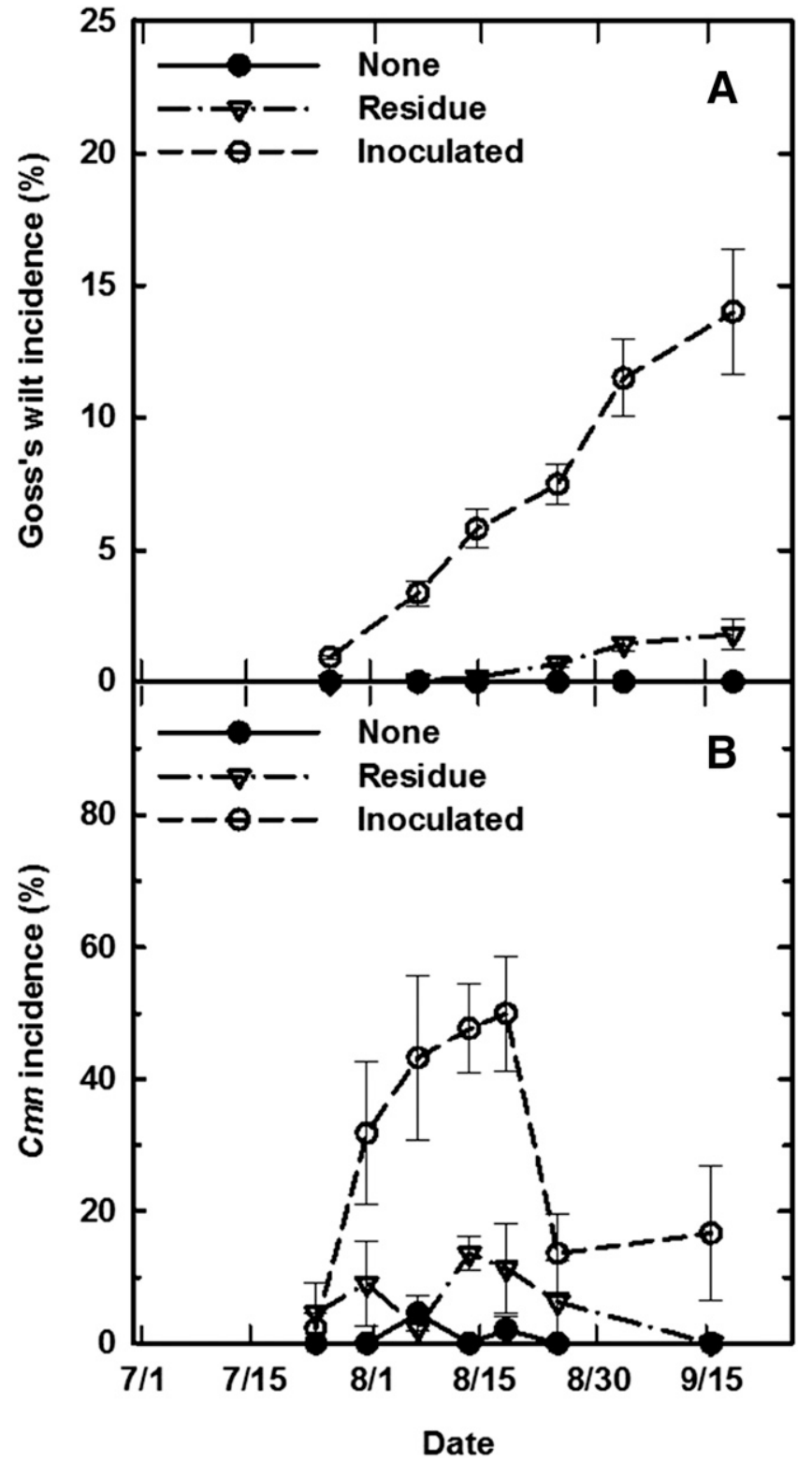

Fig. 3. A, Incidence (\%, $n=400)$ of corn plants (DeKalb DKC55-09) with Goss's wilt symptoms and $\mathbf{B}$, incidence of asymptomatic leaf samples on which epiphytic Clavibacter michiganensis subsp. nebraskensis was detected in 2013. Inoculum point sources were established in plots near Gilbert, IA on 10 July (19 days after planting) by pinprick inoculation of four plants or by placing $C$. michiganensis subsp. nebraskensis-infested residue at the base of four plants. Asymptomatic leaves from two plants were sampled from 12 quadrat locations per plot. 
michiganensis subsp. nebraskensis-positive samples (Fig. 2B), although epiphytic incidence was significantly lower than that in residue-inoculated plots only on 20 July $(P=0.0062)$ and 17 August $(P=0.0517)$.

In 2013, the incidence of $C$. michiganensis subsp. nebraskensispositive samples peaked in mid-August (19 August, crop development stage R1), as in 2012. However, peak incidence (50, 11, and $2 \%$ in wound-, residue-, and noninoculated control plots, respectively; Fig. 3B) was much lower than in 2012. In wound-inoculated plots, incidence of $C$. michiganensis subsp. nebraskensis-positive samples increased over time during the first five sample dates. In residue-inoculated and noninoculated treatments, the incidence of C. michiganensis subsp. nebraskensis-positive samples fluctuated throughout the 2013 growing season. On all sample dates in 2013, epiphytic $C$. michiganensis subsp. nebraskensis was not detected in one or more residue-inoculated inoculated plots; therefore, incidence of C. michiganensis subsp. nebraskensis-positive samples in residueinoculated and noninoculated plots was not significantly different on individual sampling dates $(P>0.10)$. However, total incidence of $C$. michiganensis subsp. nebraskensis-positive samples over the season was greater in residue-inoculated plots than in noninoculated control plots $(P=0.0170)$. On the last sample date in 2013, epiphytic C. michiganensis subsp. nebraskensis was recovered from the woundinoculated treatment but not from the residue-inoculated or noninoculated treatments. Epiphytic C. michiganensis subsp. nebraskensis was recovered from $29.0 \%( \pm 2.6 \%), 6.5 \%( \pm 1.3 \%)$, and $0.9 \%( \pm 0.5 \%)$ of all samples collected from wound-inoculated, residue-inoculated, and noninoculated plots, respectively, during the 2013 season. In 2013, C. michiganensis subsp. nebraskensis was detected on only three individual samples from the noninoculated treatment: from two noninoculated plots on 7 August and one noninoculated plot on 19 August.

Early-season incidence of $C$. michiganensis subsp. nebraskensispositive samples on 10 July 2012 was correlated with disease incidence on three subsequent sampling dates in 2012 (24 July, 17 August, and 30 August; $r=0.66$ to $0.96, P>r<0.05$ ) but most of the association was explained by early symptoms in the four wound-inoculated plots, and linear relationships were not identified

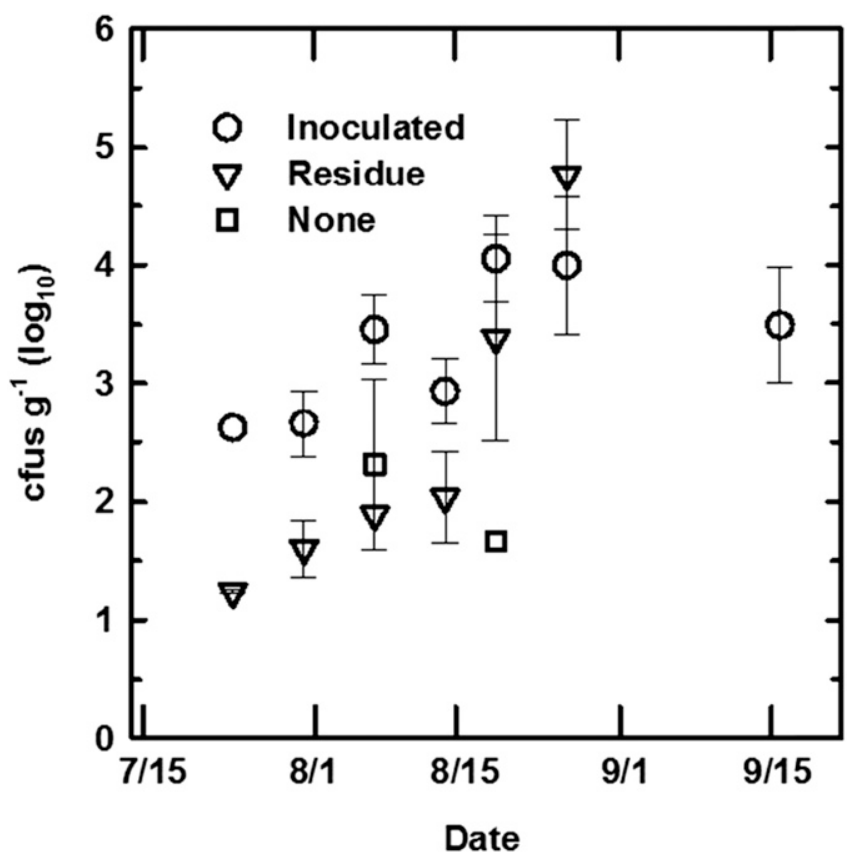

Fig. 4. Mean population densities of epiphytic Clavibacter michiganensis subsp. nebraskensis detected in washings of asymptomatic corn leaves sampled from a Goss's wilt-susceptible hybrid (DeKalb DKC55-09) in plots near Gilbert, IA, on seven dates during the 2013 growing season. Inoculum point sources were created on 10 July (19 days after planting) as wound-inoculated plants (circles) or $\mathrm{C}$. michiganensis subsp. nebraskensis-infested residue (triangles). (data not shown). In 2013, epiphytic incidence on 7, 14, 19, and 26 August (growth stages V11, V13, R1, and R2, respectively) was correlated with Goss's wilt incidence on all assessment dates from 31 July to the end of the season ( $r=0.74$ to $0.97 ; P<0.05$ ). In both years, final disease incidence in individual plots was correlated with the number of days between planting and dates when lesions were first noted in plots $(r=-0.65$ and -0.75 in 2012 and 2013, respectively; $P<0.05$ ).

Epiphytic population density. In 2013, the mean population density of epiphytic $C$. michiganensis subsp. nebraskensis detected on asymptomatic leaf tissue was $1.6 \times 10^{3} \mathrm{CFU} \mathrm{g}^{-1}$. Epiphytic population densities detected on individual samples ranged from $1.6 \times 10^{1}$ $\mathrm{CFU} \mathrm{g}{ }^{-1}$ fresh leaf tissue to $4.4 \times 10^{7} \mathrm{CFU} \mathrm{g}^{-1}$. Considerable variation in epiphytic population densities was seen in all three treatments (Fig. 4). Treatment differences were not evident on most sample dates $(P>0.10)$ but, on 31 July, mean $C$. michiganensis subsp. nebraskensis population densities in wound-inoculated plots exceeded mean densities in residue-inoculated plots by a factor of 10 ( 1 unit on the $\log _{10}$ scale; $P>t=0.0727$ ). Averaged over the entire season, epiphytic population densities were higher $(3.39 \pm 0.15$ on the $\log _{10}$ scale) in the wound-inoculated treatment than in the residue-inoculated treatment $(2.58 \pm 0.32 ; P=0.0333)$. However, mean epiphytic population densities in residue-inoculated plots increased from $2.1 \pm 0.4$ (before lesions were present) to 3.6 \pm 0.5 (after lesions were present) (data not shown). Mean population density in noninoculated controls $(2.10 \pm 0.84)$ was not different from earlyseason or season-long mean densities in the residue-inoculated treatment $(P>0.10$; Fig. 5).

Spatial pattern. In both years and both inoculated treatments, the spatial pattern of plants with Goss's wilt symptoms was generally aggregated (Figs. 6 and 7). In 2012, plants with Goss's wilt symptoms were aggregated in $90.0 \%$ of the instances when ordinary runs could be calculated. In 2013, 79.4\% of the plot-date instances had significantly aggregated spatial patterns of symptomatic plants. Blackwhite joins analysis results largely agreed with the ordinary runs results. Across all sampling periods, symptomatic plants were present in aggregated patterns in $93 \%$ of the instances in 2012 and in $72.2 \%$ of the instances in 2013. In 2012, several control plots also had plants with Goss' wilt lesions. The spatial pattern in these plots, however, was random.

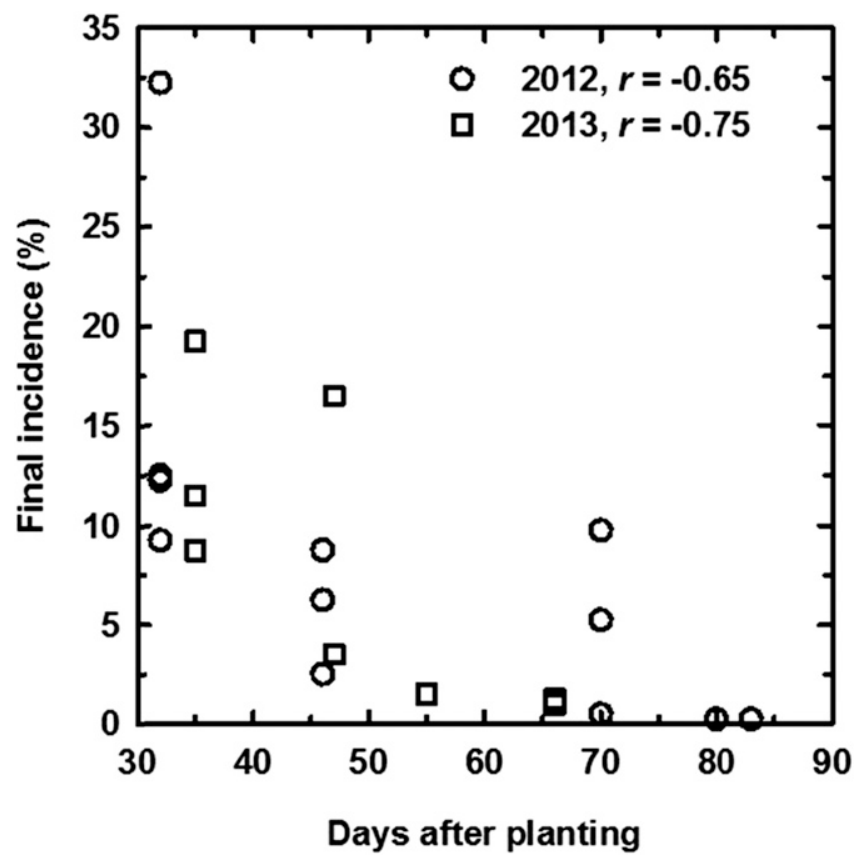

Fig. 5. Correlations between final Goss's wilt incidence and number of days after planting when symptoms were first seen in plots in field studies conducted in 2012 and 2013 near Ames, IA. Pearson correlation coefficients are significant at $P<0.05$. 


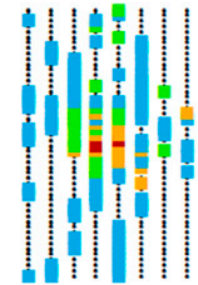

W

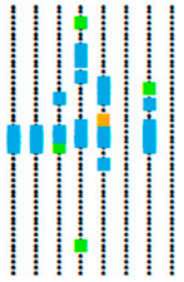

$\mathrm{R}$

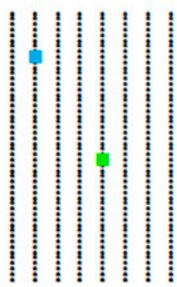

$\mathrm{N}$

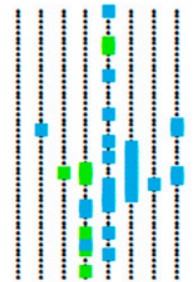

$\mathrm{R}$

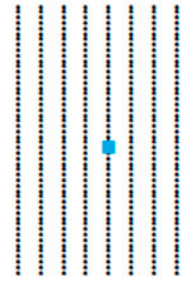

$\mathrm{N}$

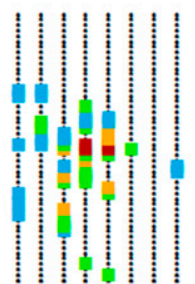

W

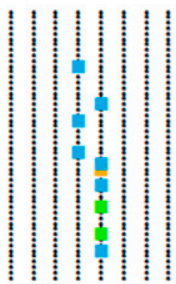

$\mathrm{N}$

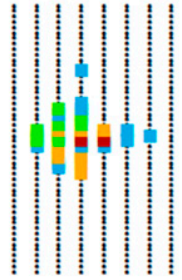

W

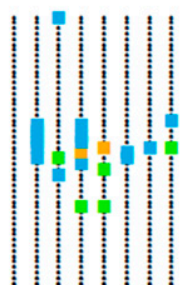

$R$

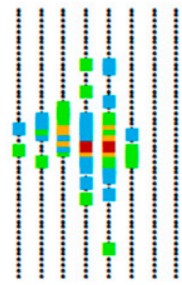

W

Fig. 6. Plot maps of 2012 field trial showing plants with Goss's wilt symptoms. Each plot was planted to a Goss's wilt-susceptible hybrid (DeKalb DKC55-09) and measured eight rows wide by 50 plants long $(6$ by $9 \mathrm{~m}$ ). A 3-m border of a Goss's wilt-resistant hybrid (DKC 56-55) surrounded each plot (not shown). W, R, and N indicate wound-inoculated, residue-inoculated, and noninoculated treatments, respectively. Colors indicate assessment date when symptoms were first recorded on each plant (red, 10 July; orange, 24 July; green, 17 August; light blue, 30 August).

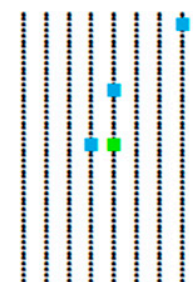

$\mathrm{R}$

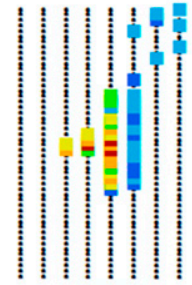

$\mathrm{W}$

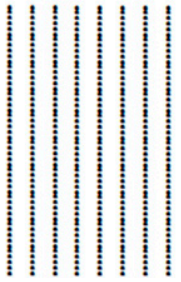

$\mathrm{N}$

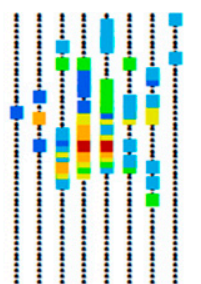

$\mathrm{W}$

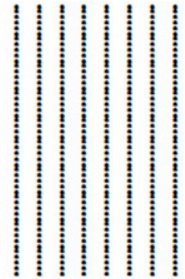

$\mathrm{N}$

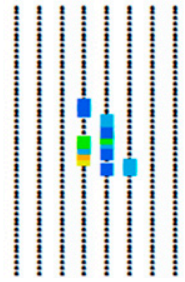

$\mathrm{R}$

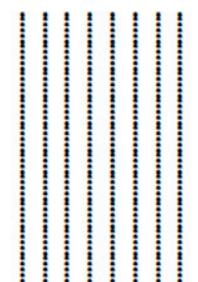

$\mathrm{N}$

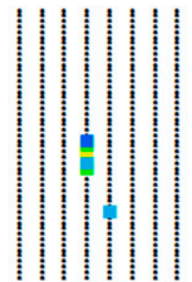

$\mathrm{R}$

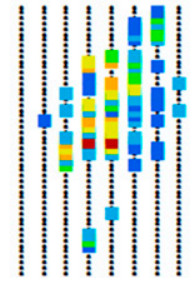

W

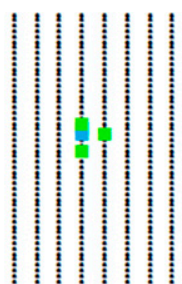

$\mathrm{R}$

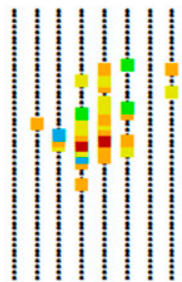

W

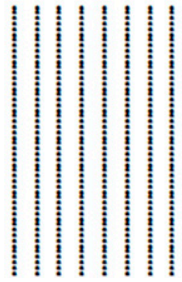

$\mathrm{N}$

Fig. 7. Plot maps of 2013 field trial showing plants with Goss's wilt symptoms. W, R, and N indicate wound-inoculated, residue-inoculated, and noninoculated treatments, respectively. Plot dimensions $(6 \mathrm{~m}$ wide by $9 \mathrm{~m}$ long) and positions are drawn to scale; four-row borders are not shown. Colors indicate date when symptoms were first recorded on each plant (red, 26 July; orange, 7 August; yellow, 15 August; green, 26 August; light blue, 4 September; dark blue, 19 September). 
Distance-based analysis. $\mathrm{D}_{50}$ and $\mathrm{D}_{95}$ varied by year and by treatment. In 2012, the average $\mathrm{D}_{50}$ distance for the wound-inoculated treatment was $0.56 \mathrm{~m}$, whereas $\mathrm{D}_{50}$ for the residue-inoculated treatment was $1.24 \mathrm{~m}$ (Table 2). These values indicate that newly symptomatic plants in wound-inoculated plots tended to be nearer to previously symptomatic plants, whereas newly symptomatic and previously symptomatic plants were farther apart in residueinoculated treatment plots $(P<0.05)$. Maximum distances between newly symptomatic and previously symptomatic corn plants and $\mathrm{D}_{95}$ showed similar patterns for wound-inoculated and residueinoculated treatments, and differences in treatment means were not significant $(P \geq 0.05)$. In $2013, \mathrm{D}_{50}$ distances for residueinoculated and wound-inoculated plots were not significantly different (Table 2).

\section{Discussion}

Our work demonstrates that $C$. michiganensis subsp. nebraskensisinfested corn residue on the soil surface is a source of inoculum for epiphytic populations of the pathogen, which can increase on asymptomatic plants throughout the growing season, and that the presence of infested residue can result in plants with Goss's wilt symptoms, even during dry growing seasons. Our findings suggest that the relatively recent expansion of Goss's wilt into new regions of the United States may be the result of a gradual, unnoticed buildup of inoculum in new areas, via movement of fauna, wind-blown residue, or aerosols from historically infested fields, which is further supported by susceptible hybrids, continuous corn production, and reducedtillage practices. Residue management and rotation to nonhost crops may help growers manage the disease from one season to the next but may not completely eliminate inoculum sources and disease risk.

Our findings suggest that $C$. michiganensis subsp. nebraskensis from residue can quickly become established as an epiphyte on corn. Smidt and Vidaver (1986) detected epiphytic C. michiganensis subsp. nebraskensis in mid-June, approximately 4 weeks after planting, and Goss's wilt in mid-July. In both 2012 and 2013, we detected epiphytic $C$. michiganensis subsp. nebraskensis 2 weeks after establishing inoculum point sources within each plot. The use of inoculum point sources and targeted sampling (near point sources) most likely improved our chances of detecting $C$. michiganensis subsp. nebraskensis sooner than Smidt and Vidaver (1986) (Kinkel 1997). In both years of our study, rainfall events occurred 10 to 14 DAI, shortly before the first sample collection dates. These rain events likely facilitated dispersal of $C$. michiganensis subsp. nebraskensis from well-developed Goss's wilt lesions, which were present on woundinoculated plants at 15 and 14 DAI. Epiphytic populations of C. michiganensis subsp. nebraskensis were also detected in residue-inoculated plots on these dates, and nonrandom patterns of Goss's wilt incidence within residue-inoculated plots suggest that disease in these plots developed from residue point sources. Although weather conditions in different locations and years influence the development and detection of epiphytic $C$. michiganensis subsp. nebraskensis populations, it is likely that commercial fields with $C$. michiganensis subsp. nebraskensis-infested residue contain plants with epiphytic $C$. michiganensis subsp. nebraskensis soon after corn seedling emergence.

The rates of disease increase observed in our study clearly document the type of disease increase that can occur in very dry years, which are usually unfavorable for disease development. Substantially faster rates occurred in plots with wound-inoculated plants than in plots where $C$. michiganensis subsp. nebraskensis-infested residue was used to establish inoculum point sources. These rate differences can only be explained by timing of initial infection, because pathogen strain, host hybrid, and environmental conditions were the same in both treatments. After lesions are present, the bacteria oozes out of diseased tissue (Jackson et al. 2007), more inoculum is present, and disease increase proceeds at a faster rate. We observed that plots with earlier initial symptoms had higher levels of final disease incidence. Smidt and Vidaver (1986) noted that disease development in June was correlated with end-of-season disease severity levels. These data support the importance of delaying the onset of disease symptoms.

We saw considerable variation in epiphytic population densities on asymptomatic leaves, and found no relationship between population density of epiphytic $C$. michiganensis subsp. nebraskensis with the incidence of $C$. michiganensis subsp. nebraskensis-positive samples. Mean population densities calculated using all samples (including zeroes; that is, samples without detected $C$. michiganensis subsp. nebraskensis) mimicked trends seen in plots of epiphytic incidence over time (data not shown). This suggests that sampling to determine the incidence of epiphytic $C$. michiganensis subsp. nebraskensis on leaves is an adequate measure of increase in epiphytic populations; quantification of detected populations by dilution plating may not yield much additional information.

Previous studies with other plant pathosystems have identified relationships between epiphytic population densities and disease severity. Lindemann et al. (1984a,b) identified relationships between epiphytic population densities and disease severity in the bean halo blight-common bean pathosystem (Pseudomonas syringae on Phaseolus vulgaris). Smidt and Vidaver (1986) recovered high epiphytic C. michiganensis subsp. nebraskensis populations $\left(10^{3}\right.$ to $\left.10^{11} \mathrm{CFU} \mathrm{g}^{-1}\right)$ from commercial popcorn fields and associated symptom development with a threshold population of $10^{7} \mathrm{CFU} \mathrm{\textrm {g } ^ { - 1 }}$ fresh weight. The leaf sampling criteria used in their study was not described. Because we restricted sampling to asymptomatic leaves in order to assess epiphytic population trends at potential infection sites, we were not able to identify relationships among epiphytic population density, epiphytic population incidence, and disease incidence. Population density estimates or incidence estimates based on entire individual leaves may potentially be more useful for estimating disease severity (Hirano et al. 1982). The corn leaves we sampled were large, and only a portion of each leaf was sonicated and used for determining population densities. Furthermore, we bulked leaf pieces from four leaves in each sample. We likely recovered much lower populations $\left(<10^{7} \mathrm{CFU} \mathrm{g}^{-1}\right)$ than Smidt and Vidaver (1986) because of our sampling method. Leaves with active infections would most likely have much higher $C$. michiganensis subsp. nebraskensis population densities, because the bacteria can often be observed oozing out of blighted tissue (Jackson et al. 2007).

Anecdotal reports describe "sudden" outbreaks of Goss's wilt following severe storms. Wise et al. (2009) suggested that storms that occurred early in the growing season contributed to the introduction and dispersal of the pathogen in northwest Indiana. In our 2012 study, the most severe weather event of the summer occurred on $25 \mathrm{July}$, when heavy rain and 40-plus mph $\left(66 \mathrm{~km} \mathrm{~h}^{-1}\right)$ winds lodged many of the plants in the trial, just 1 day after 24 July, when low incidence of Goss's wilt was detected in inoculated plots. In 2013, C. michiganensis subsp. nebraskensis was detected in plots before storms occurred on 22 July 2013, although initial infections were limited to fewer plants than in 2012. Incidence of epiphytic C. michiganensis subsp. nebraskensis increased two- to fourfold in plots after these storms; higher incidence of Goss's wilt symptoms was

Table 2. Mean distances from plants with Goss's wilt symptoms, identified on previous assessment dates, to $50 \%\left(D_{50}\right)$, 95\% ( $\left.D_{95}\right)$, or $100 \%$ ( $\left.D_{\text {max }}\right)$ of new plants with Goss's wilt symptoms in 2012 and $2013^{\mathrm{a}}$

\begin{tabular}{lcccccc}
\hline & \multicolumn{3}{c}{$\mathbf{2 0 1 2}$} & \multicolumn{2}{c}{$\mathbf{2 0 1 3}$} \\
\cline { 2 - 6 } Treatment & $\mathbf{D}_{\mathbf{5 0}}(\mathbf{m})$ & $\mathbf{D}_{\mathbf{9 5}}(\mathbf{m})$ & $\mathbf{D}_{\mathbf{m a x}}(\mathbf{m})$ & $\mathbf{D}_{\mathbf{5 0}}(\mathbf{m})$ & $\mathbf{D}_{\mathbf{9 5}}(\mathbf{m})$ & 2.19 \\
Wound-inoculated & $0.56^{*}$ & 1.92 & 2.88 & 0.45 & 2.97 \\
Residue-inoculated & $1.24^{*}$ & 2.47 & 3.59 & 0.70 & 1.82 & 1.97 \\
\hline
\end{tabular}

a Asterisks $(*)$ indicate that distances for wound- and residue-inoculated treatments are significantly different at $P=0.05$. 
observed on the next assessment dates, 17 August 2012 (23 days later) and 5 August 2013 (12 days later). These observations suggest that severe storms assisted with dispersal of $C$. michiganensis subsp. nebraskensis from corn leaves in aerosols and, consequently, increased disease incidence.

Despite the fact that we observed increased incidence of Goss's wilt after severe storms, our studies do not support the hypothesis that single storm events will result in sudden outbreaks with high disease incidence. Our data suggest that local $C$. michiganensis subsp. nebraskensis dispersal gradients can be steeper than expected. After the storm in 2012, symptoms of Goss's wilt increased from 4 to $7 \%$ (from 16 to 28 plants) in the wound-inoculated plots and 1 to $3 \%$ (from 4 to 12 plants) in the residue-inoculated plots. Symptomatic plants were clustered close to the source of inoculum or, in 2012, occurred as single plants in the control plots (Fig. 6). These levels of disease could easily go unnoticed, particularly if Goss's wilt occurred in a small area within a large field, yet the area could constitute an effective source of initial inoculum for subsequent corn crops, especially in fields with continuous-corn production and reduced tillage. Based on these data, we suggest that "sudden outbreaks" of the disease may involve multiple infection cycles over more than one growing season.

The fact that spatial patterns of Goss's wilt-infected plants in the field are mostly aggregated has important implications with regards to sampling and the quantification of yield losses (Madden and Nutter 1995; Nutter 2002). Because infected plants tend to be aggregated within cornfields, a systematic sampling design should be employed when disease intensity (e.g., incidence or severity) is assessed in corn fields (Byamukama et al. 2011; Madden and Nutter 1995). Because the spatial pattern of infected plants is aggregated, there is less opportunity for healthy plants to compensate for yield loss via increased seed number and increased seed weight (Hughes et al. 1989; Madden et al. 2007; Nutter 2001), because infected plants are more likely to be neighbored by other Goss's wilt-infected plants.

\section{Acknowledgments}

We thank A. Demirci, A. Greff, D. Miller, S. Toporek, M. S. Rivera, and J. Shriver for invaluable assistance with field and laboratory procedures. Funding for these studies was provided by Monsanto Company and the United States Department of Agriculture NC IPM grant number 2011-34103-30714: "To enhance understanding of factors that contribute to Goss's wilt and leaf blight development on corn".

\section{Literature Cited}

Abendroth, L. J., Elmore, R. W., Boyer, M. J., and Marlay, S. K. 2011. Corn Growth and Development. Iowa State University Extension, Ames.

Beattie, G. A., and Marcell, L. M. 2002. Comparative dynamics of adherent and nonadherent bacterial populations on maize leaves. Phytopathology 92: 1015-1023.

Biddle, J. A. 1990. Epidemiology and seed transmission of Goss's bacterial wilt and blight in corn. Ph.D. dissertation, Iowa State University, Ames.

Biddle, J. A., Braun, E. J., and McGee, D. C. 1985. Epidemiology and seed transmission of Goss's wilt in corn. (Abstr.) Phytopathology 75:962.

Biddle, J. A., McGee, D. C., and Braun, E. J. 1990. Seed transmission of Clavibacter michiganense subsp. nebraskense in corn. Plant Dis. 74:908-911.

Byamukama, E., Robertson, A. E., and Nutter, F. W., Jr. 2011. Quantifying the within-field temporal and spatial dynamics of Bean pod mottle virus in soybean. Plant Dis. 95:126-136.

Calub, A. G., Schuster, M. L., Compton, W. A., and Gardner, C. O. 1974. Improved technique for evaluating resistance of corn to Corynebacterium nebraskense. Crop Sci. 14:716-718.

Campbell, C. L., and Madden, L. V. 1990. Introduction to Plant Disease Epidemiology. Wiley-Interscience, New York.

Chen, C., Nace, G. W., and Irwin, P. L. 2003. A $6 \times 6$ drop plate method for simultaneous colony counting and MPN enumeration of Campylobacter jejuni, Listeria monocytogenes, and Escherichia coli. J. Microbiol. Methods 55:475-479.

Claflin, L. E. 1999. Goss's bacterial wilt and blight. Pages 4-5 in: Compendium of Corn Diseases, 3rd ed. D. G. White, ed. American Phytopathological Society, St. Paul, MN.

Daugrois, J. H., Boisne-Noc, R., and Rott, P. 2014. Leaf surface colonization of sugarcane by Xanthomonas albilineans and subsequent disease progress vary according to the host cultivar. Plant Dis. 98:191-196.

Friskop, A., Kinzer, K., McConnell, M., Liu, Z., Korus, K., Zimmerman, A., and Jackson, T. 2014. First report of Goss's bacterial leaf blight and wilt of corn caused by Clavibacter michiganensis subsp. nebraskensis in North Dakota. Plant Dis. 98:1739.

Givens, W. A., Shaw, D. R., Kruger, G. R., Johnson, W. G., Weller, S. C., Young, B. G., Wilson, R. G., Owen, M. D. K., and Jordan, D. 2009. Survey of tillage trends following the adoption of glyphosate-resistant crops. Weed Technol. 23: 150-155.

Gleason, M. L., Braun, E. J., Carlton, W. M., and Peterson, R. H. 1991. Survival and dissemination of Clavibacter michiganensis subsp. michiganensis in tomatoes. Phytopathology 81:1519-1523.

Gougherty, A. V., and Nutter, F. W., Jr. 2015. Impact of eradication programs on the temporal and spatial dynamics of Plum pox virus on Prunus spp. in Pennsylvania and Ontario, Canada. Plant Dis. 99:593-603.

Hirano, S. S., Nordheim, E. V., Arny, D. C., and Upper, C. D. 1982. Appl. Environ. Microbiol. 44:695-700.

Hirano, S. S., and Upper, C. D. 2000. Bacteria in the leaf ecosystem with emphasis on Pseudomonas syringae-A pathogen, ice nucleus, and epiphyte. Microbiol. Mol. Biol. Rev. 64:624-653.

Hollier, C. A., Singh, R. A. and Frazier, R. 2014. Goss's wilt in Louisiana: Incidence, severity and loss. (Abstr.) Phytopathology 104:S2.5.

Howard, R. J., Harding, M. W., Lynn, J., Kawchuk, L. M., and Rasmussen, N. M. 2015. First report of Goss's bacterial wilt and leaf blight on corn caused by Clavibacter michiganensis subsp. nebraskensis in Alberta, Canada. Plant Dis. 99:1034.

Hughes, G. Montreal, A.R. and Vara, P.C. 1989. Characterizing the effect of spatially heterogeneous pest injury and crop yields. Crop Res. 29:37-49.

Irey, M., Gottwald, T. R., Graham, J. H., Riley, T. D., and Carlton, G. 2006. Posthurricane analysis of citrus canker spread and progress towards the development of a predictive model to estimate disease spread due to catastrophic weather events. Online publication. Plant Health Prog. doi:10.1094/PHP-20060822-01-RS

Jackson, T. A., Harveson, R. M., and Vidaver, A. K. 2007. Reemergence of Goss's wilt and blight of corn in the Central High Plains. Online publication. Plant Health Prog. doi:10.1094/PHP-2007-0919-01-BR

Jackson-Ziems, T., Langemeier, C., Korus, K., Brungart, J., Schleicher, C. Kruger, G., and Robertson, A. 2012. Update on Goss's bacterial wilt and blight of corn. University of Nebraska-Lincoln Extension. Online publication. http://www.sdaba.org/agronomyconference/pdfs/2012ZiemsWilt.pdf

Kinkel, L. 1997. Microbial population dynamics on leaves. Annu. Rev. Phytopathol. 35:327-347.

Korus, K. A., Timmerman, A. D., French-Monar, R. D., and Jackson, T. A. 2011 First report of Goss's bacterial wilt and leaf blight (Clavibacter michiganensis subsp. nebraskensis) of corn in Texas. Plant Dis. 95:73.

Langemeier, C. B. 2012. Improved understanding of factors influencing the reemergence of Goss's bacterial wilt and blight of corn. M.S. thesis, University of Nebraska-Lincoln.

Lindemann, J., Arny, D. C., and Upper, C. D. 1984a. Epiphytic populations of Pseudomonas syringae pv. syringae on snap bean and nonhost plants and the incidence of bacterial brown spot disease in relation to cropping patterns Phytopathology 74:1329-1333.

Lindemann, J., Arny, D. C., and Upper, C. D. 1984b. Use of an apparent infection threshold population of Pseudomonas syringae to predict incidence and severity of brown spot of bean. Phytopathology 74:1334-1339.

Lindemann, J., and Upper, C. D. 1985. Aerial dispersal of epiphytic bacteria over bean plants. Appl. Environ. Microbiol. 50:1229-1232.

Madden, L. V., Hughes, G., and van den Bosch, F. 2007. The Study of Plant Disease Epidemics. American Phytopathological Society, St. Paul, MN.

Madden, L. V., Louie, R., Abt, J. J., and Knoke, J. K. 1982. Evaluation of tests for randomness of infected plants. Phytopathology 72:195-198.

Madden, L.V., and Nutter, F. W., Jr. 1995. Modeling crop losses at the field scale. Can. J. Plant Pathol. 17:124-137.

Malvick, D., Curland, R. D. and Ishimaru, C. 2012. Widespread distribution of Goss's bacterial leaf blight and wilt of corn and potential variation in virulence of Clavibacter michiganensis subsp. nebraskensis in Minnesota. (Abstr.) Phytopathology 102:S4.75.

Malvick, D., Syverson, R., and Mollov, D. 2010. Goss's bacterial blight and wilt of corn caused by Clavibacter michiganensis subs. nebraskensis occurs in Minnesota. Plant Dis. 94:1064.

Nutter, F. W., Jr. 1997. Quantifying the temporal dynamics of plant virus epidemics: A review. Crop Prot. 16:603-618.

Nutter, F. W., Jr. 2001. Disease losses. Pages 340-350 in: Encyclopedia of Plant Pathology. O. C. Maloy and T. D. Murray, eds. John Wiley and Sons, New York

Nutter, F. W., Jr., Schultz, P. M., and Hill, J. H. 1998. Quantification of withinfield spread of soybean mosaic virus in soybean using strain-specific monoclonal antibodies. Phytopathology 88:895-901.

Pataky, J. K. 1985. Relationships among reactions of sweet corn hybrids to Goss' wilt, Stewart's bacterial wilt, and northern corn leaf blight. Plant Dis. 69: 845-848.

Pérombelon, M. C. M. 1992. Potato blackleg: Epidemiology, host-pathogen interaction and control. Neth. J. Plant Pathol. 98:135-146.

Rocheford, T. R., Vidaver, A. K., Gardner, C. O., and Arabrust, D. L. 1985. Effect of wind-generated sand abrasion on infection of corn (Zea mays L.) by Corynebacterium michiganense ssp. nebraskense. (Abstr.) Phytopathology $75: 1378$ 
Rouse, D. I., Nordheim, E. V., Hirano, S. S., and Upper, C. D. 1985. A model relating the probability of foliar disease incidence to the population frequencies of bacterial plant pathogens. Phytopathology 75:505-509.

Ruhl, G., Wise, K., Creswell, T., Leonberger, A., and Speers, C. 2009. First report of Goss's bacterial wilt and leaf blight on corn caused by Clavibacter michiganensis subsp. nebraskensis in Indiana. Plant Dis. 93:841.

Saalau Rojas, E., and Gleason, M. L. 2012. Epiphytic survival of Erwinia tracheiphila on muskmelon (Cucumis melo L.). Plant Dis. 96:62-66.

Sawada, M. 1999. Technological Tools: ROOKCASE: An Excel 97/2000 Visual Basic (VB) add-in for exploring global and local spatial autocorrelation. Bull. Ecol. Soc. Am. 80:231-234.

Schuster, M. L. 1975. Leaf freckles and wilt of corn incited by Corynebacterium nebraskense Schuster, Hoff, Mandel, Lazar, 1972. Agriculture Experiment Station, University of Nebraska-Lincoln.

Shepherd, L. 1999. Detection and transmission of Clavibacter michiganensis subsp. nebraskensis of corn. M.S. thesis, Iowa State University, Ames.
Singh, R., Hollier, C., Burks, T., and Frazier, R. 2015. First report of Goss's wilt of corn caused by Clavibacter michiganensis subsp. nebraskensis in Louisiana. Plant Dis. 99:1268.

Smidt, M., and Vidaver, A. K. 1986. Population dynamics of Clavibacter michiganense subsp. nebraskense in field-grown dent corn and popcorn. Plant Dis. 70:1031-1036.

Sweets, L., and Hosack, P. K. 2014. Goss's bacterial wilt and leaf blight of corn. Online publication. Integrated Pest and Crop Management, Division of Plant Sciences, University of Missouri. http://ipm.missouri.edu/IPCM/2014/8/Goss_sBacterial-Wilt-and-Leaf-Blight-of-Corn

Vidaver, A. K., and Mandel, M. 1974. Corynebacterium nebraskense, a new, orange-pigmented phytopathogenic species. Int. J. Syst. Bacteriol. 24: 482-485.

Wise, K., Ruhl, G., Creswell, T., Leonberger, A., and Speers, C. 2009. Occurrence and impact of Goss's bacterial wilt and leaf blight on corn in Indiana. (Abstr.) Phytopathology 99:S143. 